\title{
The Effect of Investment Toward Economic Growth in The Local Economy
}

\author{
Saadah Yuliana, Abdul Bashir, Siti Rohima \\ Department of Development Economics, Faculty of Economics \\ Universitas Sriwijaya, Indonesia \\ Email: saadahyuliana@fe.unsri.ac.id
}

Received: August 4, 2018; Accepted: December 28, 2018; Published: March 30, 2019

Permalink/DOI: http://dx.doi.org/10.17977/um002v11i12019p028

\begin{abstract}
This study aims to analyze the role of investment such as total foreign direct investment and domestic direct investment, inflation, and road infrastructure to the economic growth of South Sumatera Province, Indonesia. The data used is time series data from 2007-2016, while the scope of this study is 15 districts/cities in South Sumatera Province. The data is sourced from the publication of Central Bureau of Statistics Indonesia (BPS) and the publication of the Investment Coordinating Board (BKPM) South Sumatera Province. The analysis method in this study is quantitative analysis using data panel multiple regression model. The finding of this study showed that investment, inflation, and road infrastructure development jointly has positive and significant effect on the economic growth. Meanwhile, partially indicating that investment and road infrastructure have positive and significant impact to economic growth, while inflation has positive sign but insignificant effect on economic growth of South Sumatera Province.
\end{abstract}

Keywords: Investment; inflation; road infrastructure; economic growth JEL Classification: H54; O40; P44

\section{INTRODUCTION}

Development is essentially a multidimensional process that involves changes in social structure, national institutions, accelerating economic growth, income generation and poverty alleviation (Ngowi, 2009; Rohima et al., 2017). In order to achieve the goals of development, the activity is directed at three main points, namely an increase in the availability and distribution of basic needs for the people, improvement of people's living standards; and increase the community's ability to access economic and social activities (Todaro \& Smith, 2011). One of the goals of economic development for community is to realize a justice and prosperity for the whole society. This goal is determined by the capacity and economic capacity of a country to produce goods and services that are necessary for the needs of the community life.

Theoretically, the sum of all final goods and services produced by an economy over a certain period (usually one year) is called the national income. National income or national product is normally expressed by Gross Domestic Product (GDP) or Gross National Product (GNP). GDP calculate the production of goods and services produced by companies or foreigners operating in the territory of the country concerned, while GNP calculate the value of goods and services produced by a country's population for one year, including the production of goods 
and services produced by citizens who are abroad, but excluding the production of foreign companies operating in the territory of the country (BPS, 2016).

Gross Domestic Product (GDP) is one of the popular macroeconomic indicators to measure economic performance of a country (Yuliadi, 2009). In assessing the economic growth, generally using GDP growth at constant prices. An economy is said to grow or develop if a higher level of economic activity that had been achieved in the past. This means that the amount of goods and services produced in the economy becomes larger than in previous years. Generally, the regional economic experts argue that regional economic growth occurs as a result of factors exogenous and endogenous factors. Exogenous factors are factors that come from outside the region, one of which is the level of demand from other regions of the goods and services produced by a certain area. While endogenous factors are factors that originate from within the region include the distribution of production factors between regions.

Endogenous factors of economic development is closely related to the economic potential that can be measured on a variable private investment and government spending (Arsyad, 2010; Bergh \& Henrekson, 2011). In endogenous growth theory, the role of investment in physical capital and human capital contribute to determine the long-term economic growth. Savings and investment can encourage sustainable economic growth (Mankiw, 2000). Three important functions of investment activity that (a) the investment is one of the components of aggregate expenditure, so that the increase in investment will increase aggregate demand, national income, and employment opportunities; (b) the increase of capital goods as a result of the investment will increase production capacity; (c) investment is always followed by technologic development (Suindyah, 2011).

The investment is one of the regional macroeconomic variables has an important role in creating regional economic growth. Aurangzeb \& Haq (2012) found that the investment which include public investment, private investment and foreign direct investment has significant positive effect on economic growth. Mehra (2013) states that foreign direct investment not only limited to a simple transfer of money, but has now extended to being defined as a measure of foreign ownership of domestic productive assets such as factories, land, and organization and other intangible assets like technologies, marketing skills and managerial capabilities. At the local level, one of the tools to measure the level of prosperity namely Gross Regional Domestic Product (GRDP). Gross regional domestic product is often an indicator to see the symptoms of the regional economic growth because in reflecting the production of goods and services in a particular area (Ambarwati \& Payamta, 2015). Economic growth is the development of activities in the economy that led to goods produced in the community increases. Starting from that study, regional development is an important part of the national development. The success of regional development is the realization of national development, in which the distribution of development among regions is indispensable so that the development can be enjoyed by the whole community.

On the other side, the price level is the economic variables that play a vital role and is a strategic economic variable, because it may affect the operation of market mechanisms in an economy. The high inflation rate will have a negative impact on economic growth, high inflation will reduce economic growth. According to McCann (2010) level of commodity prices in a region can affect the 
particular region's economic growth through the operation of the mechanism of inter-regional trade. In addition, Ardiansyah (2017) in his research concluded that inflation was significant negative effect on economic growth in Indonesia.

Each region has different resources from one area to another due to differences in the geographical structure of the region with other regions (Richardson, 2011). In order to achieve the goal of regional development, it is necessary to know well the area's potential, it is necessary to empower the natural resources and human resources, and infrastructure. The shape of the interconnections between regions (linkage inter-regional) in the economic field can be: current or flow of goods and currency market chain intermediate goods and final goods, the linkage of production, the shopping patterns of consumers, pattern control and ownership of the economy, stream of income including transfers and remittances, capital flows, financial system, both formal and informal, and labour migration. Which would require the development of adequate infrastructure so that the movement of currents or the flow of goods, the linkage of production, ease of consumer shopping, everything becomes smooth. It is in line with the results of Maryaningsih et al. (2014) which states that the condition of road infrastructure and electricity have a significant impact on the growth of per capita income.

South Sumatra Province that was only 15 districts/cities become 17 districts/cities since 2015 is a province rich in natural resources. At the National Medium Term Development Plan (RPJMN) 2015-2019 Palembang designated as the Metropolitan city. The new metropolitan area includes the city of Palembang as National Activity Centers (PKN), partially District of Banyuasin, partially District of Ogan Ilir, partially District of Ogan Komering Ilir. Increasing cooperation between the strategic development areas, accompanied by an increase in physical development such as roads and other physical infrastructure directly or indirectly contribute to the economic growth of the region. The existence of road infrastructure has a very important role in supporting the ongoing activities of other sectors and serves as the infrastructure of transportation movement of raw materials for production, marketing and distribution infrastructure of the movement of goods and services produced (Rohima et al., 2017).

On the other side, South Sumatera is a province which is the goal of investors both domestic and foreign investors. High investment can affect economic growth. This is because of the multiplier effect resulting from investment activities which include employment and increase the flow of goods and services from one region to another. The role of an injection of investment for the expansion of the economic growth of the region through infrastructure development and other capital expenditures (Dewan \& Hussein, 2001; Gylfason \& Zoega, 2006; Rasmidatta, 2011). Consideration is because the investment is still the main supporting factor in driving growth in Indonesia (Adisasmita, 2008). In respect of the effect of the investment on economic growth, Maryaningsih et al. (2014) found that the empirically proven investment as push factor of economic growth in Indonesia.

The above description explains that investment is the main supporting factor in driving economic growth, as well as road infrastructure development is an important factor in promoting economic growth, and that the price level is an economic variable that plays an important role and is strategic economic variables that have an impact on economic growth. This study is intended to assess the role of the investment such as the total of foreign direct investment and domestic direct 
investment, inflation, and road infrastructure to the economic growth of South Sumatera Province, Indonesia.

\section{METHOD}

This study investigates the role of the investment, inflation, and road infrastructure to economic growth. The scope of analysis in this study is districts/cities in South Sumatera province. The study was conducted within the scope of 15 districts/cities in South Sumatera Province of the period 2007-2016. The analysis method of this study uses quantitative analysis with multiple regression to see the effect of the investment, inflation, and road infrastructure to the economic growth of South Sumatera. The data used in this study is secondary data such as time series data, sourced from the publication of Central Bureau of Statistics Indonesia (BPS) South Sumatera and publication of Investment Coordinating Board (BKPM) South Sumatera. Mathematically, the relationship between variables can be expressed in equation terms as follows:

$$
\mathrm{Y}_{\mathrm{it}}=\alpha_{0} \mathrm{I}_{\mathrm{it}}^{\alpha_{1}} \mathrm{Z}_{\mathrm{it}}^{\alpha_{\mathrm{n}}} \mu^{\mathrm{u}}
$$

Equation (1) is adapted from the production function of Cobb-Douglas which is a non-linear model form, where, $Y$ is economic growth; $I$ is investment; and $Z$ is control variable; notation $i$ is region; $t$ is years; notation $\alpha_{0}$ is constant coefficient; notation $\alpha_{1}, \alpha_{n}$ is parameters coefficient; and $\mu$ is error term. The next, equation (2) is a function that to see factors influencing economic growth:

$$
\mathrm{GRDP}=\mathrm{f}(\mathrm{INV}, \mathrm{CPI}, \mathrm{ROAD})
$$

Equations (2) and (3) showed the relationships between variables in the equation (3) are transformed into a semi-logarithm, while the linear regression equation model is presented as follows:

$$
\operatorname{lnGRDP}{ }_{i, t}=\alpha_{o}+\alpha_{1} \operatorname{lnINV}_{i, t}+\alpha_{2} C P I_{i, t}+\alpha_{3} \ln R O A D_{i, t}+\mu_{t}
$$

Where: the variable of GRDP is economic growth; INV is an investment; CPI is inflation; ROAD is road infrastructure; $t$ is years; notation $\alpha_{0}$ is constant coefficient; notation $\alpha_{1}, \alpha_{2}, \alpha_{3}$ is parameters coefficient; and $\mu$ is error term. The definition of operational variables can be presented as follows:

Table 1. Data and Source

\begin{tabular}{llcc}
\hline Variable & \multicolumn{1}{c}{ Descriptions } & Unit & Source \\
\hline GRDP & $\begin{array}{l}\text { The total production of goods and services } \\
\text { by the various sectors of the economy in a } \\
\text { region (constant price 2010). }\end{array}$ & rupiah & BPS \\
\hline INV & $\begin{array}{l}\text { The realization data of domestic investment } \\
\text { and foreign direct investment. }\end{array}$ & rupiah & BKPM \\
\hline CPI & $\begin{array}{l}\text { Index that measures the average change in } \\
\text { prices over time of goods and services } \\
\text { consumed by the inhabitants or households } \\
\text { in urban areas with a certain base year. }\end{array}$ & Index & BPS \\
\hline
\end{tabular}




\begin{tabular}{lll}
\hline ROAD & $\begin{array}{l}\text { The data of road length in South Sumatera, } \\
\text { which consists of the country road length, } \\
\text { provincial road, and district/city road. }\end{array}$ & BPS \\
\end{tabular}

Source: Author's (2018)

\section{RESULTS AND DISCUSSION}

\section{Gross Regional Domestic Product Development}

Gross Regional Domestic Product (GRDP) is an indicator to see the symptoms of economic growth because GRDP reflects the activity in production of goods and services. Economic progress in South Sumatera province is the aggregate of economic progress in the district/city. Each region contributes based on the capabilities and characteristics of each of the economic growth of South Sumatera province.

Figure 1 indicated that the average distribution GRDP by the expenditure during 2007-2016. The type of expenses covered household consumption expenditure; expenditure of non-profit institutions serving households; government consumption expenditures; changes in inventories; and Export and Import of Foreign Affairs. The distribution GRDP by expenditure using based on the current price, for indicating the economic structure in South Sumatera. The average contribution of household consumption expenditure is high enough to GRDP of South Sumatera Province of $65.07 \%$ during 2007-2016. High relatively of the contribution of household consumption expenditure to gross regional domestic product and average growth in household consumption expenditure, indicating the economic growth of South Sumatera Province. Household consumption expenditures directly cover various household final consumption expenditure on goods and services to meet the needs of individuals or groups. Household expenditures include food and beverages in addition to restaurants, clothing, footwear and maintenance services, housing and household supplies, health and education, transport and communications, restaurants, and hotels, as well as other (BPS, 2017).

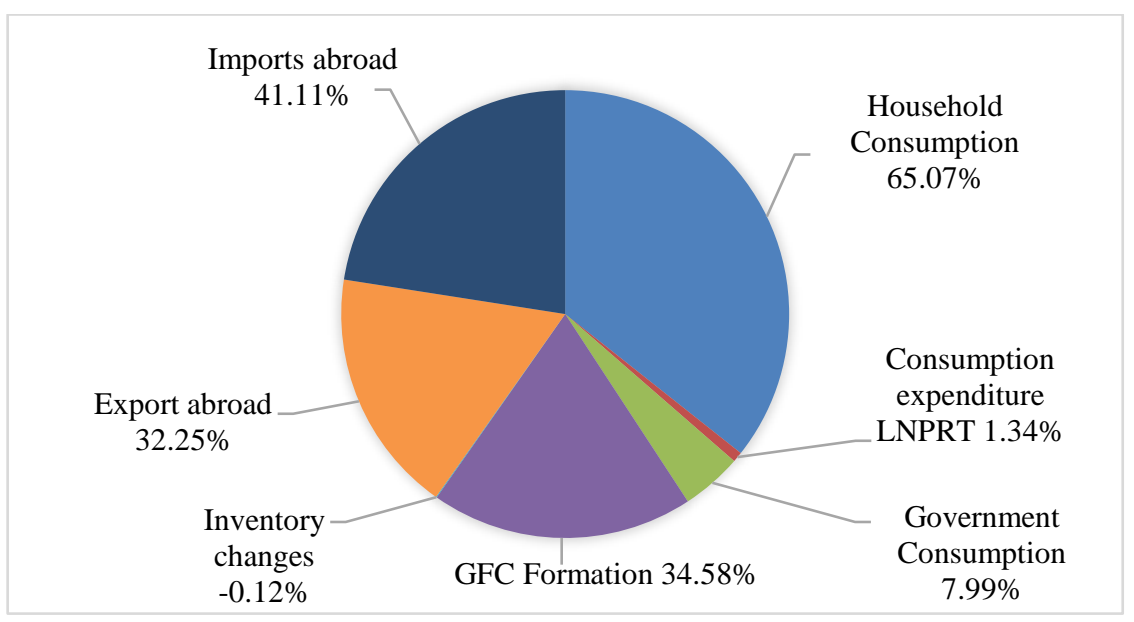

Figure 1. The distribution of GRDP by expenditure in South Sumatera, 2007-2016 Source: BPS of South Sumatera Province (various editions)

Meanwhile, the average contribution of expenditure of non-profit institutions serving households by $1.34 \%$ per year in the same period, while the average 
contribution of government consumption to gross regional domestic product amounted to $7.99 \%$. Furthermore, the average contribution of gross fixed capital formation by $34.58 \%$ in the same period. In addition, the average contribution of export and import abroad by $32.25 \%$ and $41.11 \%$, the high contribution of import compared export its caused by non-oil import such as capital goods covering the commodity comes from machinery or electrical equipment, fertilizers, materials from stone, casts, and cement, including ceramic products.

\section{Trend of Investment}

Investment is one of the macroeconomic variables in creating economic growth. GRDP is the sum of many variables, including the investment. During the period from 2007-2016 the foreign investment realization [Foreign Direct Investment (FDI)] in South Sumatera to fluctuate. Nominally increased in 2012, 2014 and 2016, then a slight decline in 2013 and 2015, and increased again in 2016. In 2007-2013 although nominally increased, but the rate of increase of FDI is volatile, namely $228 \%$ in 2010 , then increased by $199 \%$ in 2011 and decreased by $38.21 \%$ in 2013 . The decline in investment by FDI in nominal terms occurred in 2013 and 2015. On average during 2007-2016 investment by FDI rose by $82.70 \%$ per year.

The investment is one of the regional macroeconomic variables has an important role in creating regional economic growth. Realization of investment by domestic direct investment (DDI) for the period 2007-2016 indicated to fluctuate. Significant increases occurred in 2010, 2012 and 2014 the amount of 199\%, 174\%, and $107 \%$. In 2013, domestic investment increased by $15.88 \%$, or from 2,931 billion rupiahs in 2012 to 3,396 billion rupiahs in 2013. While the decrease by 2016 the value of domestic investment increased occur in 2011 and 2016 the amount of $-38.51 \%$ and $-22.02 \%$. During the period $2007-2016$ by domestic investment (DDI) increased by an average increase of $54.65 \%$ per year (Figure 2).

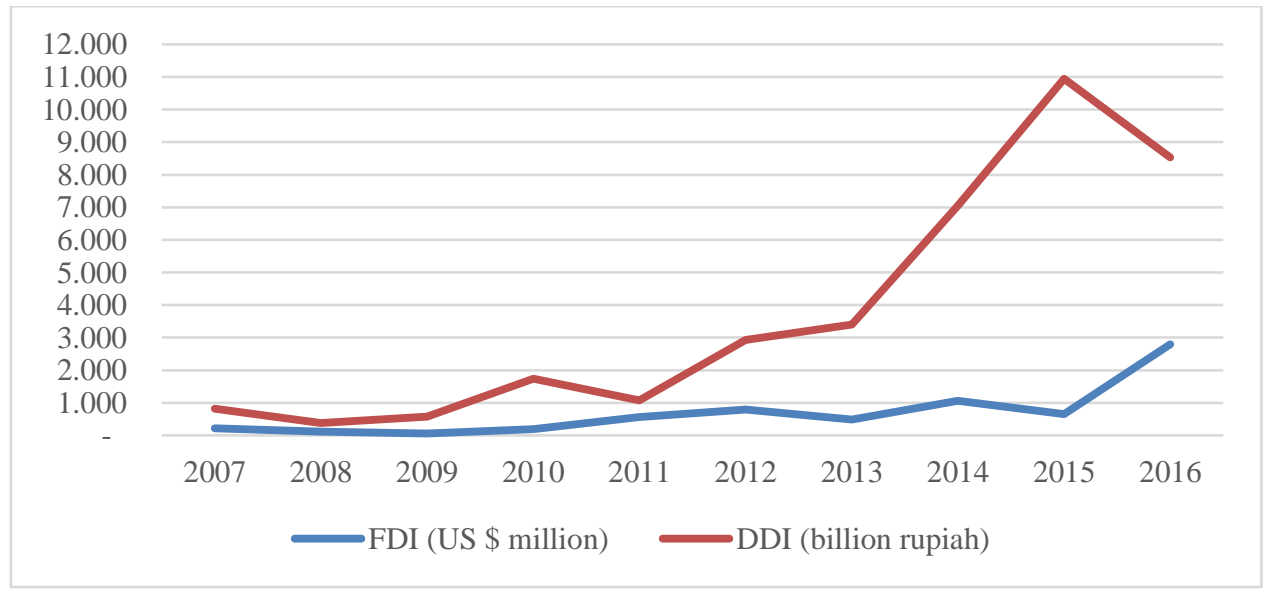

Figure 2. The trend of foreign direct investment (FDI) and domestic investment (DDI) realization in South Sumatera Province, 2007-2016

Source: Investment Coordinating Board (BKPM) South Sumatera (various editions)

South Sumatera Province is a province which is the goal of investors both domestic and foreign investors. High investment value can affect economic growth because the investment has the multiplier effect resulting from investment activities 
which include employment rate and increase the flow of goods and services from one region to another. The role of investment as an injection for the expansion of economic growth in South Sumatera Province through infrastructure development and other capital expenditures.

\section{Trend of Inflation}

Economic growth is the development of activities in the economy that led to goods produced in the community increases. The high inflation rate will have a negative impact on economic growth. Changes in commodity prices level in South Sumatera Province could lead to economic growth through the operation of the market mechanism. The growth of Inflation in South Sumatera Province reflected in the growth of the consumer price index (inflation) of Palembang. Figure 3 provides a comparison of high inflation in the South Sumatera Province with the national inflation.

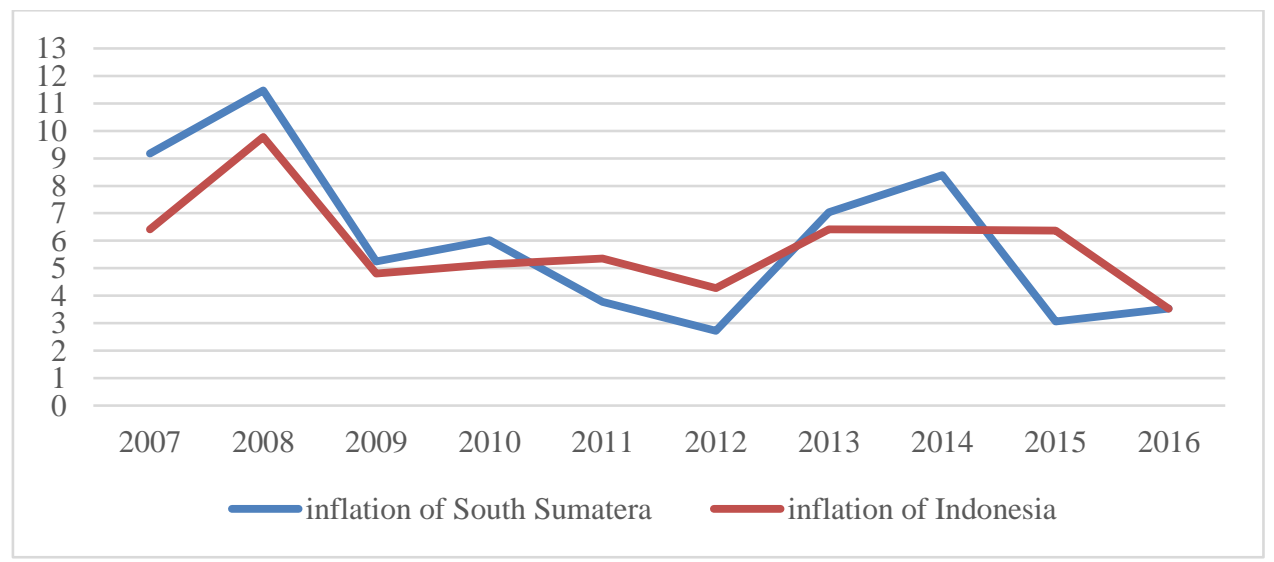

Figure 3. The Inflation trend of South Sumatera Province and Indonesia, 2007-2016 Source: BPS of South Sumatera (various editions)

Inflation can be calculated by expenditure group that includes spending on foodstuffs; food, beverages, and tobacco products; housing, water, electricity, and fuel; clothing; health groups; education group recreation and sport, as well as transport and communication group. Among the various groups such spending, generally the largest contributor to inflation is the processed food, beverages, cigarettes, and tobacco. During 2007-2016 the trend of inflation in South Sumatera and National level has fluctuated, there is decline in the rate of inflation in 2011 and 2012, as well as an increase in 2013 and 2014. For the national level, inflation decreased in 2012 but has increased in the years thereafter. During the period 20072016 the highest inflation in the region of South Sumatera occur in Palembang city compared to another region, while in South Sumatera and National level the highest inflation rate in 2008 and 2014.

\section{Road Infrastructure Development}

The existence of road infrastructure has a very important role in supporting the ongoing activities of other sectors, and serves as the infrastructure of transportation movement of raw materials for production, marketing and distribution infrastructure of the movement of goods and services produced. This 
indicates that the physical infrastructure, especially road infrastructure contributes to economic growth.

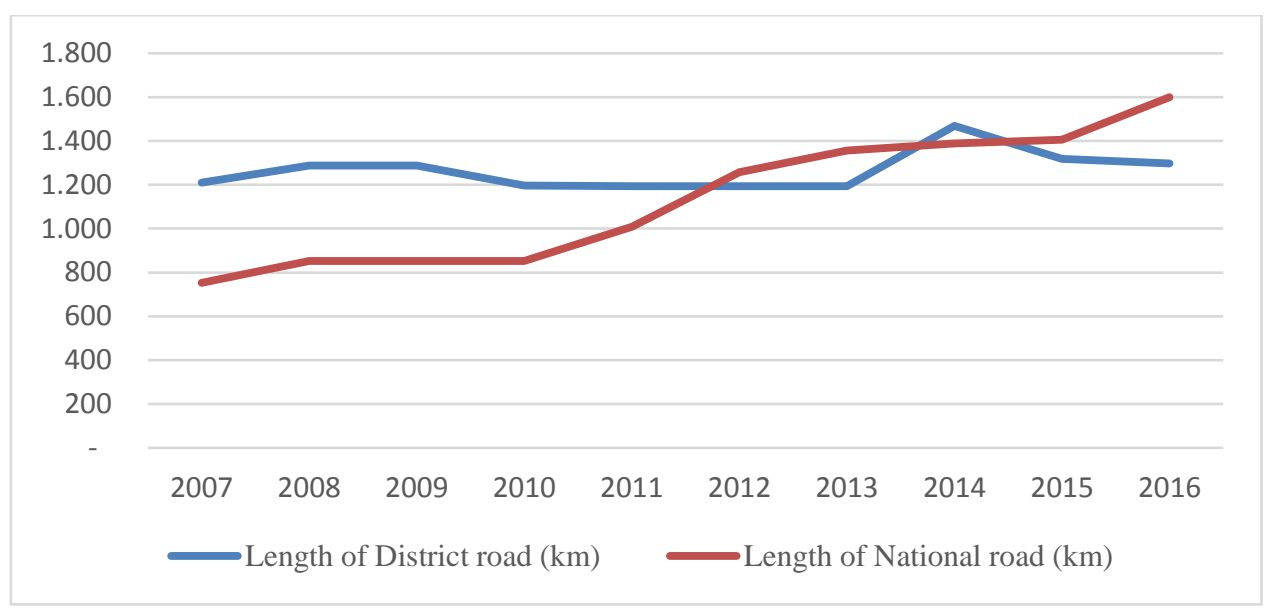

Figure 4. The road length of district/city and National $(\mathrm{km})$ in South Sumatera, 2007-2016 Source: BPS of South Sumatera (various editions)

During 2007-2016 the condition of the good roads in South Sumatera and National level has the increase. In 2014 the construction of the good roads in South Sumatera throughout 1469 kilometers, while for the condition of the good roads national throughout 1389 kilometers (Figure 4). The road length in South Sumatera during 2007-2016, the average of roads length with the good condition of 1265 kilometers, while the longest road construction of roads in the region of South Sumatera is East OKU District compared to the construction of roads in another districts/cities. District/city over the course of the construction of 100 kilometers in 2014 was Ogan Komering Ulu District, South OKU District, Ogan Ilir District, and Empat Lawang District. In 2015, among all districts/cities in South Sumatera province is the longest road development in East OKU District, while other districts over the course of the construction of 100 kilometers namely Muara Enim, Lahat, South OKU, and Ogan Ilir.

Palembang as the capital of South Sumatera Province had been constructed the road in 2014 along the 83.91 kilometers, or $5.7 \%$ of the total road's length constructed during the year. In 2015, the construction of roads in Palembang decreased to 64.81 kilometers or $4.4 \%$ of the total length of roads constructed during the year. There are relatively little roads in the city of Palembang in 2015 because next year in 2016-2018 South Sumatera provincial government undertakes the construction of toll roads. A significant increase in the construction of the road is in Lahat District is of 89.91 kilometers in 2014 to 177.52 kilometers by 2015, or an increase of $97.4 \%$. This is because Lahat is a crossing between districts/cities in the vicinity.

\section{The result of Model Estimation}

Based on the best model test results by using Hausman test and chow test, then we will use a fixed effect estimation model to see the influence of investment, inflation, and road length on the economic growth can be expressed in the following Table 2. 
Table 2. Result of Model Estimation

\begin{tabular}{llrccc}
\hline Variable & Description & Coefficient & S.E & t-stat & Prob. \\
\hline c & constant & 10.3265 & 0.79898 & 12.9246 & 0.0000 \\
lnINV & investment & 0.19311 & 0.07111 & 2.71549 & 0.0006 \\
CPI & consumer price index & 0.00335 & 0.00237 & 1.41258 & 0.1696 \\
lnROAD & road length & 0.00323 & 0.00152 & 2.12500 & 0.0011 \\
\hline Obs & & 150 & & & \\
$\mathrm{R}^{2}$ & & 0.78513 & & & \\
f-test & & 31.6674 & & & \\
\hline
\end{tabular}

Source: Authors calculation (2018)

The estimation results in Table 2 indicated that the coefficient of investment, inflation, and road infrastructure development is positive, it means that each of these variables has a positive influence on economic growth in the province of South Sumatera. Jointly, these three variables influence significantly, it can be seen from the value of f-test of 31.6674 where this figure is greater than the value of f-table by 4.02. Meanwhile, the determination coefficient of 0.78513 means that the variation of the variable investment, inflation, and the development of road infrastructure is able to explain $78.5 \%$ of the variation of economic growth variables province of South Sumatera, while the remaining $21.5 \%$ is explained by other variables outside the model.

Meanwhile, partially indicates that only the investment and road infrastructure development has significant effect on economic growth. This can be seen from the probability value ( $\mathrm{p}$-value) of each variable is smaller than $0.05(\alpha=$ $5 \%$ ). While the inflation variable has a p-value greater than 0.05 it indicates that inflation has insignificant impact on the economic growth in South Sumatera Province. Furthermore, in Tabel 4 show that the constant value of 10.3265 , means that if there is no investment, inflation, and road infrastructure development, economic growth will increase by $10.32 \%$. The constant value is enough high indicate there are other factors outside model has relatively high on effect to economic growth of South Sumatera Province.

In Table 2 show that coefficient value of investment of 0.19311 means that if there is an increase of $1 \%$ of investment, then the economic growth will increase by $0.193 \%$, assuming other factors are considered constant. These finding indicated that investment has positive sign and significant effect on economic growth, means that the higher the investment, the higher the economic growth. Investment is one of the macroeconomic variables in creating economic growth, so that the investment will bring multiplier effects on other macroeconomic variables, such as employment, consumption, exports, and so on. The results are consistent with research Maryaningsih et al. (2014) found that investment empirically proved as push factor of economic growth in Indonesia. The results are consistent with research Wahyuni (2004) which states that investment a significant effect on economic growth and have a positive effect on economic growth. This opinion strengthened by Makmun \& Yasin (2003) who conclude that investment as a key for economic growth, because instead of push significantly increase in output, there are automatically will increase the demand of input, next turn will increase the prosperous of community. 
The coefficient value of inflation of 0.00335 means that if there is an increase of $1 \%$ inflation, then the economic growth will increase by $0.00335 \%$, assuming other factors are considered constant. However, it does not significantly influence economic growth. These findings are not consistent with research Ardiansyah (2017) which show that the inflation significantly negative effect on economic growth in Indonesia. Generally, inflation is required in moving the economy, because inflation will encourage the real sector to increase production, it is this which will lead to greater economic growth. In this case inflation has positive effect on the economy. However, if inflation or price increases have exceeded the purchasing power of the people, then the output is generated manufacturers do not sell, resulting in a reduction in production and a reduction in labor force, unemployment, such things will not stimulate economic growth. In this condition, the absence of inflation will be a negative effect on economic growth.

Furthermore, coefficient value of road infrastructure of 0.000323 means that if an increase in the construction of road infrastructure by $1 \%$ economic growth will increase by $0.000323 \%$, ceteris paribus. The road infrastructure has positive and significant effect on economic growth, means that more roads were built in the district/city, the higher the economic growth of South Sumatera Province. This study in line with the study done by Cahyono \& Kaluge (2011) using the Error Correction Model with time series data to see the impact of Public Infrastructure to Gross Domestic Product per capita in Indonesia. The study states that the road infrastructure affects the Gross Domestic Product per capita in Indonesia for the long term, but does not affect the Gross Domestic Product per capita in Indonesia in the short term. Brittain (2002) argued that the infrastructure available and well maintained is essential to facilitate the economic activity of a city and improve the quality of life for its residents. Current economic activity and quality of population can increase productivity and revenue. In addition, according to Rohima et al. (2017) the availability of well-maintained public infrastructure is critical to the economy of a district/city for the quality of life of its population. On the other side, infrastructure as the engine of economic growth and welfare of society in the region of Indonesia. Availability of good roads should be held in each region so that the mobility of goods and services, as well as flow of people from one area to another to be smooth. Likewise, in South Sumatera, more roads are built will facilitate access to the movement of goods produced one area to be sent to other areas. Such circumstances are mutually supportive and conducive overall will increase economic activity and economic growth in South Sumatera.

\section{CONCLUSION}

From these findings, several points can be concluded among others, that the investment, inflation, and road infrastructure development jointly has significant effect on the economic growth in South Sumatera Province. Partially, the variable of investment and road infrastructure development has positive sign and significant effect to the economic growth, however, the variable of inflation has positive sign but insignificant effect to the economic growth of South Sumatera Province. Investment is one of the macroeconomic variables in creating economic growth, so the investment will bring multiplier effects on other macroeconomic variables, such as employment, consumption, exports, and so on. Meanwhile, the road infrastructure has positive and significant effect on economic growth means that 
more roads were built in the district/city it will push the economic growth of South Sumatera Province, Indonesia.

\section{REFERENCES}

Adisasmita, R. (2008). Regional Development: Concepts and Theories (Pengembangan Wilayah: Konsep dan Teori). Yogyakarta: Graha Ilmu Publisher.

Ambarwati, A., \& Payamta. (2015). The Effect of Locally-Generated Revenue, Government Investment and Labor Force on GRDP of District/City in Java (Pengaruh Pendapatan Asli Daerah, Investasi Pemerintah dan Angkatan Kerja terhadap PDRB Kabupaten/Kota di Jawa). ASSETS: Jurnal Akuntansi Dan Pendidikan, 4(1), 37-52.

Ardiansyah, H. (2017). The Effect of Inflation on Economic Growth in Indonesia (Pengaruh Inflasi terhadap Pertumbuhan Ekonomi di Indonesia). Jurnal Pendidikan Ekonomi, 5(3), 1-5.

Arsyad, L. (2010). Ekonomi Pembangunan (4th ed.). Yogyakarta: STIE-YKPN.

Aurangzeb., \& Haq, A. U. (2012). Impact of Investment Activities on Economic Growth of Pakistan. Business and Management Review, 2(1), 92-100.

Badan Pusat Statistik. (2016). Statistik Indonesia. Jakarta: Badan Pusat Statistik.

Bergh, A., \& Henrekson, M. (2011). Government Size and Growth: A Survey and Interpretation of the Evidence (No. 858). Working Paper. Stockholm, Sweden: Research Institute of Industrial Economics.

Brittain, L. S. (2002). Financing capital expenditures. Canadian Tax Journal, 50(2), $552-575$.

Cahyono, E. F., \& Kaluge, D. (2011). Analisis Pengaruh Infrastruktur Publik Terhadap Produk Domestik Bruto Perkapita di Indonesia. Iqtishoduna, 7(2), $1-20$.

Dewan, E., \& Hussein, S. (2001). Determinants of Economic Growth in G20 Countries: A Panel Data Approach. In Working Paper (pp. 1-52). Fiji: Reserve Bank of Fiji.

Gylfason, T., \& Zoega, G. (2006). Natural Resources and Economic Growth: The Role of Investment. The World Economy, 29(8), 1091-1115. https://doi.org/10.1111/j.1467-9701.2006.00807.x

Makmun., \& Yasin, A. (2003). The Effect of Investment and Labor on Agricultural Sector GDP (Pengaruh Investasi dan Tenaga Kerja terhadap PDB Sektor Pertanian). Kajian Ekonomi Dan Keuangan, 7(3), 1-15.

Mankiw, G. N. (2000). Macroeconomics Theory (Teori Makroekonomi) (4th ed.). Jakarta: Erlangga Publisher.

Maryaningsih, N., Hermansyah, O., \& Savitri, M. (2014). The Effect of Infrastructure on Indonesia's Economic Growth (Pengaruh Infrastruktur terhadap Pertumbuhan ekonomi Indonesia). Buletin Ekonomi Moneter dan Perbankan, 17(1), 62-98. https://doi.org/10.21098/bemp.v17i1.44

McCann, D. (2010). The Political Economy of the European Union. Cambridge: Polity Press. https://doi.org/10.1111/j.1468-5965.2011.02172_2.x

Mehra, N. (2013). Impact of Foreign Direct Investment on Employment and Gross Domestic Product in India. International Journal of Economic Research, 4(4), 29-38. 
Ngowi, H. P. (2009). Economic Development and Change in Tanzania since Independence: The Political Leadership Factor. African Journal of Political Science and International Relations, 3(4), 259-267.

Rasmidatta, P. (2011). The Relationship Between Domestic Saving and Economic Growth and Convergence Hypothesis: Case Study of Thailand. In Master Thesis: Sodertorn University (pp. 1-79). Sodertorn University.

Richardson, H. W. (2011). Basics of Regional Economics (Dasar-Dasar Ilmu Ekonomi Regional). (Paul Sitohang, Ed.) (1st ed.). Jakarta: BPFE Universitas Indonesia.

Rohima, S., Yuliana, S., Bashir, A., \& Hafiz, N. (2017). Public Infrastructure Availability on Development Disparity. Business and Economic Research, 7(2), 375-391. https://doi.org/10.5296/ber.v7i2.11983

Suindyah, S. (2011). The Effect of Investment, Labor and Government Expenditure on Economic Growth in East Java Province (Pengaruh Investasi, Tenaga Kerja dan Pengeluaran Pemerintah terhadap Pertumbuhan Ekonomi di Propinsi Jawa Timur). EKUITAS, 15(4), 477-500.

Todaro, M. P., \& Smith, S. C. (2011). Economic Development in Third World (Pembangunan Ekonomi Dunia Ketiga). (Agus Darma, Ed.) (11th ed.). Jakarta: Erlangga Publisher.

Wahyuni, H. (2004). The Role of Government in Economic Growth: Evidence from Asia and Pasific Countries. Journal of Indonesian Economy and Business, 19(1), 1-16.

Yuliadi. (2009). The Indonesian Economy: Problems and Policy Implementation (Perekonomian Indonesia: Masalah dan Implementasi Kebijakan) (1st ed.). Yogyakarta: BPFE Universitas Gadjah Mada. 